ллучай анкилостомидоза в практике врача-дерматовенеролога

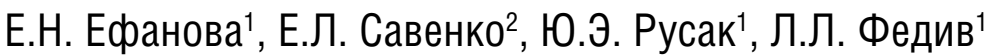

1 БУ ВО «Сургутский государственный университет ХМАО — Югры» 628412, г. Сургут, Ханты-Мансийский автономный округ — Югра, пр. Ленина, д. 1

${ }^{2}$ Медико-санитарная часть 000 «Газпром трансгаз Сургут» 628403, г. Сургут, Ханты-Мансийский автономный округ — Югра, ул. 50 лет ВлКСМ, д. 3/1

Представлено наблюдение анкилостомидоза (мигрирующая кожная личинка), гельминтоза из группы нематодозов.

Описана диагностика и лечение анкилостомидоза у 28-летнего пациента, прибывшего из эндемичного района.

Ключевые слова: анкилостомидоз, нематодозы, мигрирующая кожная личинка, поражение кожи стоп.

Контактная информация: el.efanova2011@yandex.ru. Вестник дерматологии и венерологии 2016; (1): 69—72.

\title{
Ancylostomiasis case in a physician-dermatologist practice
}

\author{
E.N. Efanova ${ }^{1}$, E.L. Savenko², J.E. Rusak', L.L. Fediv ${ }^{1}$
}

${ }^{1}$ Surgut State University, Khanty-Mansi Autonomous Area - Yugra

Lenina str., 1, Surgut, Khanty-Mansi Autonomous Okrug — Yugra, 628412, Russia

2 Gazprom Transgaz Surgut, LLC Medical Unit

50 years of the VLCSM str., 3/1, Surgut, Khanty-Mansi Autonomous Area - Yugra, 628403, Russia

Hookworm disease (larva migrans) observation of a nematosis worms group is presented. Diagnosis and the treatment

of a 28-year-old patient from an endemic area, who has hookworm disease, are described.

Key words: hookworm disease, nematosis, migrating larva, feet dermhelminthiasis. 
В настоящее время в практике врача-дерматовенеролога нередко встречаются непрофильные заболевания, имеющие кожные проявления, в том числе и гельминтозы.

Актуальность проблемы обусловлена участившимися случаями завоза гельминтозов с кожными проявлениями за счет активной миграции населения и туризма. На этом фроне возрастает интерес к «тропической» дерматологии.

Анкилостомидоз (сыпь рудокопов, земляная чесотка, египетский хлороз) - гельминтоз из группы нематодозов. Всего в мире насчитывается 576 млн больных анкилостомидозом. У большинства больных заболевание протекает бессимптомно [1, 3].

Возбудители анкилостомидоза - паразитические круглые черви из рода анкилостом (Ancylostoma). Наиболее распространенными являются $A$. duodenale и N. americanus [3].

Строение: половозрелая особь красно-коричневого цвета, самка длиной 9-15 мм, самец 7-10 мм, головной конец загнут на спинную сторону (отсюда название - кривоголовка). На головном конце находится ротовая капсула с 4 режущими зубцами. В нее открываются протоки двух желез, секрет которых препятствует свертыванию крови. Яйца овальные, бесцветные, с тонкой оболочкой. Размер яиц $66 \times 38$ мкм. В свежевыделенных яйцах в центре находятся 4-8 зародышевых клеток. При исследовании через сутки внутри можно увидеть личинку [3, 4].

Заражение анкилостомидозом происходит при контакте с землей, в которой обитают личинки анкилостомы (например, при хождении босиком по земле или песку личинки анкилостомы могут проникнуть в организм человека через кожу); при употреблении в пищу овощей и фруктов, загрязненных личинками анкилостомы.

Географическое распространение анкилостомидозов обусловлено наличием эндемичных очагов преимущественно субтропических и тропических стран - Южная Азия, страны Африки, Центральная и Южная Америка, Австралия, где подвергается инвазии до 45-50\% местного населения. Периодически анкилостомидозы встречаются и в странах с умеренным климатом (Италия, Сербия и др.). Из близлежащих стран в эпидемических сводках фригурируют Грузия, Азербайджан, Туркмения, Казахстан, Узбекистан [1-4].

Клинические проявления. В месте проникновения возбудителя через 1-2 дня на коже появляется красная зудящая точка, покраснение, отек. Такая картина, названная земляной чесоткой, чаще всего наблюдается на ступнях и сохраняется в течение 1-2 нед.

Массивная инвазия может приводить к отекам конечностей. Когда личинки анкилостомы попадают в органы дыхания (стадия легочной миграции), у человека возникают одышка и кашель, иногда с кровью.
Примерно через месяц после проникновения в организм человека личинки анкилостомы поражают пищеварительный тракт, и у человека появляются гастроинтестинальные симптомы. Характерны симптомы поражения ЦНС: слабость, быстрая утомляемость, одышка, головокружение, потемнение в глазах, шум в ушах, отставание в умственном и фризическом развитии [1-4].

Специфическая диагностика анкилостомидоза:

- сероиммунологические методы - РСК, РНГА, ИФА и др.;

в период миграционной фазы обнаружение личинок в крови и мокроте, рентгенография органов грудной клетки (транзиторные легочные инфильтраты во время легочной миграции паразита);

в период хронической фразы: овоскопия фекалий, реже - дуоденального содержимого; гельминтоскопия фекалий - при высокой степени инвазии анкилостомы в фрекалиях могут быть обнаружены невооруженным глазом [3, 5].

\section{Описание клинического случая}

Пациент А., 1987 г. рождения, житель г. Сургута, консультирован 20.08.2014 в связи с кожными высыпаниями. Предъявлял жалобы на высыпания на коже правой стопы, сопровождающиеся чувством жжения, покалывания, умеренным зудом, болезненностью.

Анамнез заболевания: считает себя больным около 1 нед., когда появились высыпания на коже правой стопы. Начало заболевания связывает с поездкой в Таиланд, хождением босыми ногами по пляжу. За медицинской помощью не обращался. Самостоятельно использовал раствор фукорцина без эффекта.

Эпидемиологический анамнез: жилищно-бытовые условия удовлетворительные. Возникновение заболевания связывает с поездкой в эндемичную зону (Таиланд) с 08.08.2014 по 18.08.2014. Наличие парентеральных манипуляций медицинского и немедицинского характера за последние 6 мес. отрицает. Контакт с инфекционными больными отрицает. Из близкого окружения заболевших нет. Ранее глистными инвазиями не болел.

Анамнез жизни без особенностей.

Объективно: общее состояние удовлетворительное. Температура тела $36,7^{\circ} \mathrm{C}$. Сознание ясное, реакция на осмотр адекватная. Телосложение правильное, нормостеническое. Менингиальной и очаговой неврологической симптоматики нет. Слизистые оболочки влажные, фризиологической окраски. Перифрерические лимфатические узлы не увеличены. Со стороны внутренних органов и систем без патологии. Стул и диурез не нарушены.

Локальный статус: патологический кожный процесс носит ограниченный характер. На коже подошвенной поверхности правой стопы отмечается очаг умеренной гиперемии, на поверхности единичные па- 
пуловезикулы, склонные к слиянию в гирляндоподобные формы, с относительно четкими границами, размером в ширину до 0,2 см, в длину до 4,0 см. Кожа слегка отечна, при пальпации ощущается уплотнение, умеренная болезненность.

Результаты дополнительных методов обследования:

Гемограмма при обращении: Нb - 117 г/л, эр. $3,04 \cdot 10^{12} /$ л, тр. $-127 \cdot 10^{9} /$ л, л. $-9,8 \cdot 10 /{ }^{9}$ л, с. $-68 \%$, э. - 2\%, лимфр. - 26\%, мон. - 4\%; СОЭ - 15 мм/ч.

Общий анализ мочи: удельный вес 1020, pH 5,5, белок и глюкоза не обнаружены, лейкоциты 2-3 в поле зрения, эритроциты не обнаружены.

Кал на яйца гельминтов - не обнаружено.

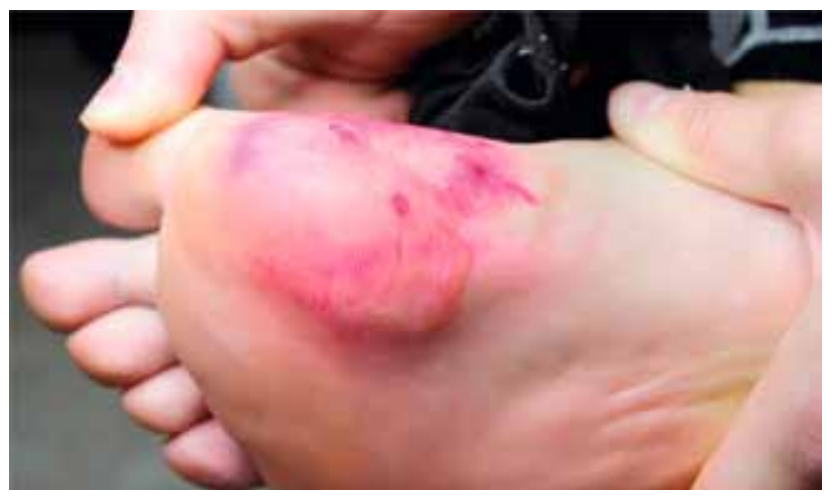

a
На основании жалоб, анамнеза, клинического осмотра и эпидемиологических данных поставлен клинический диагноз: В76.9 Анкилостомидоз неуточненный. Миграция личинок в коже БДУ.

В лечении совместно с врачами-инфекционистами назначено: мебендазол 100 мг в сутки после еды (3 дня), краска Кастеллани, крем Белогент 2 раза в день на очаг поражения 10 дней.

На фроне лечения отмечена положительная динамика в виде частичного регресса высыпаний, отсутствия уплотнения и болезненности при пальпации. Свежих высыпаний на коже и видимых слизистых не обнаружено (рис. 1, 2).

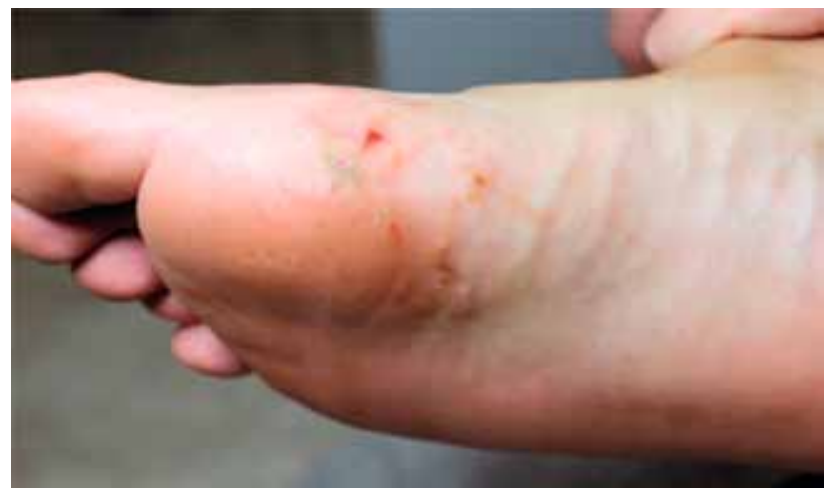

$\sigma$

Рис. 1. Клинические проявления анкилостомидоза неуточненного (стадия мигрирующей личинки) на коже подошвенной поверхности правой стопы: $а$ — до лечения; б - после лечения

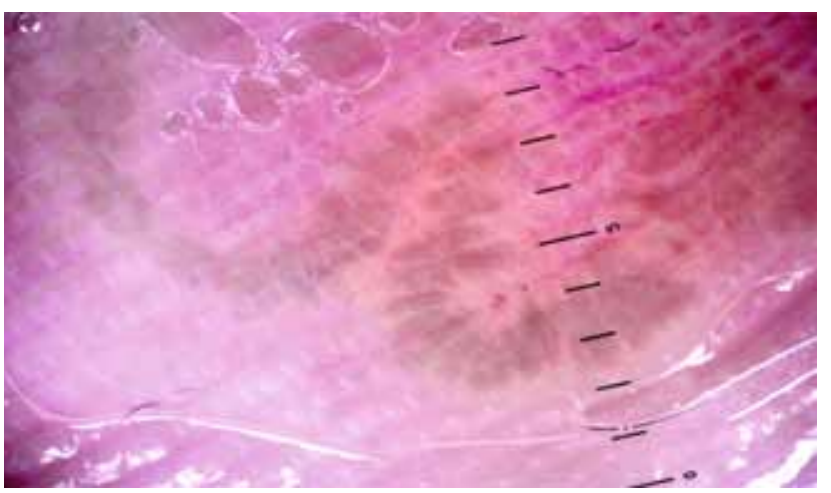

a

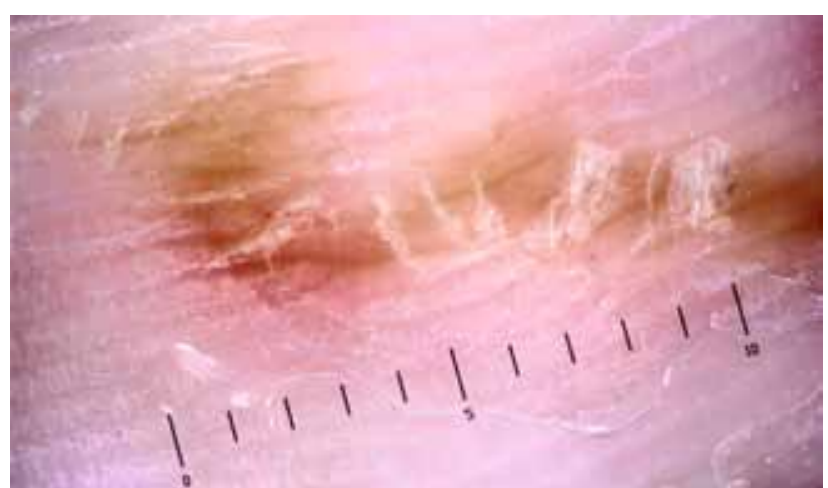

6

Рис. 2. Дерматоскопическая картина анкилостомидоза неуточненного (стадия мигрирующей личинки). ×10: $a$ - до лечения; $\sigma$ - после лечения 


\section{Заключение}

Для правильной диагностики кожных проявлений гельминтоза необходимы доскональный сбор анамнеза и фризикальное исследование. Обзор кожных проявлений должен учитывать первоначальную картину поражения, ее динамику, анатомическое распространение, топографоанатомические особенности локализации высыпаний. Учитывая активные выезды граждан Российской Федерации за пределы страны, врачам-дерматовенерологам необходимо иметь «настороженность» по тропическим дерматозам.

\section{Литература}

1. Uchaykin V.F. Atlas detskih infektsionnyih zabolevaniy: atlas-spravochnik. M: GEOTAR-Media 2009; 30-32. [Учайкин В.Ф. Атлас детских инсекционных заболеваний: атлас-справочник. М: ГЭОТАР-Медиа 2009; 30_32.]

2. Skripkin Yu.K., Mordovtsev V.N. Kozhnyie i venericheskie bolezni: rukovodstvo dlya vrachey. M: Meditsina 1999; (1): 424. [Скрипкин Ю.К., Мордовцев В.Н. Кожные и венерические болезни: руководство для врачей. М: Медицина 1999; (1): 424.]
3. Dermatologiya Fitspatrika $v$ klinicheskoy praktike: ucheb posobie. K. Volf i dr. T. 3. M: BINOM 2013; 2622. [Дерматология Фицпатрика в клинической практике: учеб пособие. К. Вольф и др. Т. 3. М: БИНОМ 2013; 2622.]

4. Lobzin Yu.V., Kozlov S.S., Uskov A.N. Rukovodstvo po infektsionnyim boleznyam $s$ atlasom infektsionnoy patologii. M: Meditsina 2000; 348.
[Лобзин Ю.В., Козлов С.С., Усков А.Н. Руководство по инсрекционным болезням с атласом инфекционной патологии. М: Медицина 2000; 348.]

5. Babayants R.S. Kozhnyie i venericheskie bolezni zharkih stran: monografiya. M: Meditsina 1972; 270-275. [Бабаянц Р.С. Кожные и венерические болезни жарких стран: монография. М: Медицина 1972; 270-275.]

об авторах:

Е.Н. Ефранова — к.м.н., доцент кафредры инсрекционных, кожных и венерических болезней медицинского института

БУ ВО «Сургутский государственный университет ХМАО — Югры»

Е.Л. Савенко - к.м.н., врач-дерматовенеролог высшей квалиффикационной категории медико-санитарной части

000 «Газпром трансгаз Сургут»

Ю.Э. Русак — д.м.н., профессор, зав. кафедрой инсрекционных, кожных и венерических болезней медицинского института

БУ ВО «Сургутский государственный университет ХМАО — Югры»

Л.Л. Федив - клинический ординатор кафедры инфекционных, кожных и венерических болезней медицинского института

БУ ВО «Сургутский государственный университет ХМАО — Югры»

\section{Конфликт интересов}

Авторы заявляют об отсутствии потенциального конфрликта интересов, требующего раскрытия в данной статье 